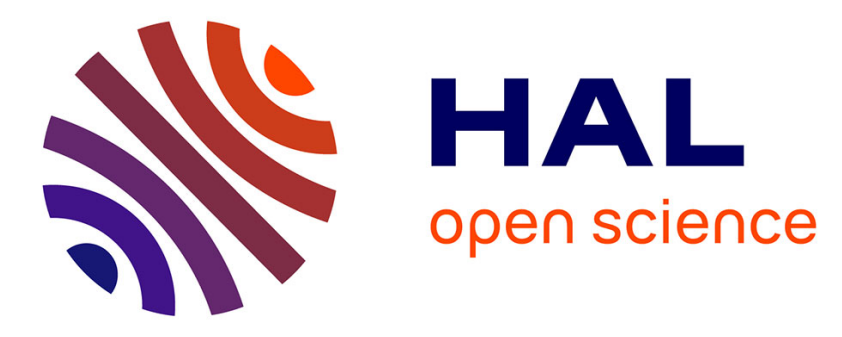

\title{
State of the Art in the Eco-Design Field: Toward Specifications for the Integration of Eco-Design in the Automotive Sector
}

Julien Garcia, Dominique Millet, Pierre Tonnelier

\section{- To cite this version:}

Julien Garcia, Dominique Millet, Pierre Tonnelier. State of the Art in the Eco-Design Field: Toward Specifications for the Integration of Eco-Design in the Automotive Sector. ASME 2012 11th Biennial Conference on Engineering Systems Design and Analysis, 2012, Nantes, France. pp.637-646, 10.1115/ESDA2012-82321 . hal-01723888

\section{HAL Id: hal-01723888 \\ https://hal-univ-tln.archives-ouvertes.fr/hal-01723888}

Submitted on 13 Feb 2020

HAL is a multi-disciplinary open access archive for the deposit and dissemination of scientific research documents, whether they are published or not. The documents may come from teaching and research institutions in France or abroad, or from public or private research centers.
L'archive ouverte pluridisciplinaire HAL, est destinée au dépôt et à la diffusion de documents scientifiques de niveau recherche, publiés ou non, émanant des établissements d'enseignement et de recherche français ou étrangers, des laboratoires publics ou privés. 


\section{STATE OF THE ART IN THE ECO-DESIGN FIELD: TOWARD SPECIFICATIONS FOR THE INTEGRATION OF ECO-DESIGN IN THE AUTOMOTIVE SECTOR}

\author{
Julien Garcia \\ PSA Peugeot Citroën \\ VV009, Route de Gisy \\ 78140 Vélizy-Villacoublay, \\ France
}

\author{
Dominique Millet \\ LISMMA/Supméca \\ Place Georges Pompidou \\ 83000 Toulon, France
}

\author{
Pierre Tonnelier \\ PSA Peugeot Citroën \\ VV009, Route de Gisy \\ 78140 Vélizy-Villacoublay, \\ France
}

\begin{abstract}
This paper lies within the integration of an eco-design method adapted to the Innovation structure at a car manufacturer. The environmental constraints in the automotive industry are more and more important (European emission standards for exhaust emissions, European directive on end-of life vehicles ...). Eco-design is a new manner to design products related to the concept of sustainable development, which combines economy and ecology and put the environmental criterion alongside the classical criterions of design. The goal of this study is to identify the specifications of a strategy for integrating the dimension "Environment". This strategy is applied in the innovation process thanks to ecodesign tools which are the learning vectors for an organization, and therefore support a learning process. This process is structured with the interactions between the management of firm, the environment department, and the design team. Therefore we first make a synthesis of the different classifications of eco-design tools and use two categories: diagnosis and improvement. Second, as our goal is the integration in the Innovation structure and within a design process, we analyze some design process models and highlight the RID (Research, Innovation structure, Development) concept. Third, the main practices of several car makers are synthetized and a focus on three of them (Volvo, Ford, and Volkswagen) is made; we link their strategies with the concept of RID. Finally in the fourth part, we propose a model of a strategy for integrating eco-design practices based on the three examples and supported by a learning process.
\end{abstract}

\section{INTRODUCTION}

The concept of sustainable development has been defined for the first time in 1987 in the report "Our Common Future" [1] of the United Nations World Commission on Environment and Development chaired by Gro Harlem Bruntland. It is a "development that meets the needs of the present without compromising the ability of future generations to meet their own needs." In the business world, this theoretical concept occurs notably with a new manner to design products which combines economy and ecology [2] and put the environmental criterion alongside the classical criterions of design such as costs, time, or quality, namely eco-design. The goal is to design more environmentally friendly products thanks to a multi-stage and multi-criteria approach, i.e. an approach which takes into account the entire lifecycle of the product, "from cradle to grave", and a set of environmental impacts.

To reach this goal, there are some methods for integrating the dimension "Environment" (or dimension "E") in the scientific literature. Two methodological trends exist: the majority methods are supported by the technical resources such as tools and software, the others are supported by the training of the design team and learning [3]. In the first category, Bauman et al. highlight that there are a lot of eco-design tools, more than 150 in 2002 [4]. However, most of them are not used in companies because they are not appropriate for the design process [5]. In the second category, Bras [6] considers that learning is "a necessary prerequisite" to use the eco-design tools.

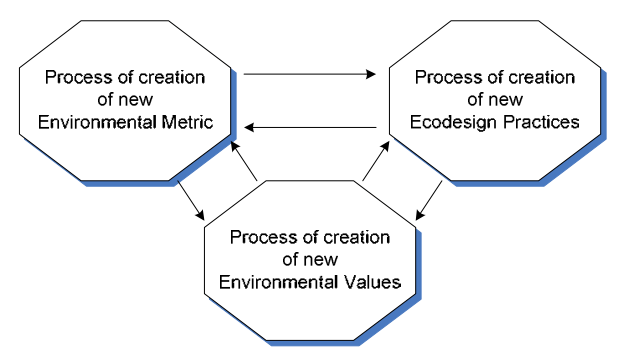

FIGURE 1 - COMPLETE INTEGRATION PROCESS [9]

Millet et al. consider that the tools are the learning vectors for an organization and remark that the dimension "E" can have 
different status according to the apprehension of the actors of design: it can be perceived as a constraint, a criterion, or a value [7], and it generates respectively a partial, classical, or innovative eco-design [8]. In this context, Jacqueson et al. proposed a "Learning Driving Tool" which assures an enhanced value monitoring of the dimension "E", i.e. to pass from constraint to criterion and value according to formalization and diffusion actions [3]. It is based on the interactions between the management of firm, the environment department, and the design team.

Therefore, Millet et al. bring together both methodological trends into a complete integration process of the dimension "E" in the design process (Figure 1) which is supported by three interdependent sub-processes [8,9]:

- "The creation of an environmental knowledge through the elaboration an environmental evaluation tool,

- The creation of new eco-design practices based on a system of tools,

- $\quad$ The creation of new governing values and new learning schemes modifying the principles, the mental models, the faiths to which every actor in his activity within the company refers."

The integration of other dimensions has been subject to studies: for example, the integration of ergonomics at the car manufacturer Renault has been analyzed [10]. Thanks to an analogy with the integration of eco-design, the goal of this study was to deduce several principles from the observation so as to propose an integration process which supports the perception of designer (constraint $\rightarrow$ criterion $\rightarrow$ value), and which is supported by the interactions between the management of firm, the ergonomics department, and the design team. The authors highlight a downstream integration approach, i.e. from the downstream parts of a project to the upstream parts, for every field of research in ergonomics. The analogy between ergonomics and environment is used in this paper, and the downstream approach is exploited.

Our project research is to integrate an eco-design method for the Innovation structure at a car manufacturer. One of the particularities of the automotive industry is that there is a "clear distinction between the vehicle development project and the innovation project" [11]. Although there is less information on the final product in the Innovation structure than in the vehicle development projects, the levers for action and improvement are higher.

In the first part of this paper, a state of the art of eco-design tools is done so as to categorize them. Then, the analysis of design and innovation process is detailed in order to determine the different possibilities to integrate the eco-design. In the third part, we make a synthesis of the main actions of car or parts manufacturers, and we make three focuses on Volvo, Volkswagen and Ford in order to highlight a strategy. Finally, the fourth part concludes the paper with the requirements and specifications for an eco-design method for the Innovation structure.

\section{CATEGORISATION OF ECO-DESIGN TOOLS}

Generally, the eco-design tools are an implemented result of the application of a specific eco-design method/approach which forms a way to manage to improve the environmental efficiency of products for equivalent criterions e.g. cost, time, quality. A lot of authors have classified and categorized the numerous eco-design tools. The goal of this part is to synthetize the various classifications of tools available in the literature.

According to Millet et al. [8], one "toolbox environment" of an eco-design method should contain at list tools of type of:

- Illustration for having a good picture of the environmental issue,

- Diagnosis to identify the environmental hotspots of the reference product,

- Definition of the objectives from the diagnosis,

- Recommendation to find areas for improvement,

- Evaluation/Classification to make the best choices thanks to a multi-criteria analysis (cost, time, quality, environment ...).

Le Pochat et al. [12] analysed the classifications of Janin [13], Tischner and Nickel [14], Van Berkel et al. [15] and Dewulf [16]. The function e.g. evaluation, improvement, or decision help, the efficiency, the usability, etc. are parameters for classifying. However, Le Pochat et al. enhanced that "the ease of these tools being used by non-experts was not considered during their development." Therefore, they developed the software EDIMS (EcoDesign Integration Method for SMEs) based on "the environmental analysis of the product" and "assistance in conducting changes in the business." This method resulted in the French standard NF E01005 [17].

Bellini and Janin [18] realized a mapping of the main classes of tools according to their evaluation level and their recommendation level on two scales from 1 to 5 . The marks of the evaluation tools are attributed according to their evaluation mode i.e. qualitative or quantitative, and their approach i.e. number of lifecycle stages and environmental criterions. The same is true for the recommendation tools which are marked according to the type of recommendation.

The study of Bovea and Pérez-Belis [19] takes three studies [20-22] completed by focusing on the early steps of the design process and the authors propose a more general classification. One of the contributions of this study is that it mentions methods for integrating classical requirements in the product design but adapted for integrating the environment. Those eco-design methods link most of the time one classical tool of design e.g. Quality Function Deployment matrix for quality, with a diagnostic or evaluation tool e.g. Life Cycle Assessment (LCA). 
TABLE 1 - CLASSIFICATION OF ECO-DESIGN METHODS AND TOOLS

\begin{tabular}{|c|c|}
\hline Diagnosis & Improvement \\
\hline - $\quad$ Analysis & - $\quad$ Recommendation \\
\hline Life Cycle Assessment [25-27] & DFE, DFX [45] \\
\hline \multicolumn{2}{|l|}{ Simplified Life Cycle Assessment $[28,29]$} \\
\hline & Guidelines \\
\hline - $\quad$ Evaluation/Classification & The Ten Golden Rules [46] \\
\hline \multicolumn{2}{|l|}{ Matrix LCA : } \\
\hline MECO [30] & Checklist \\
\hline ERPA [31] & The EcoDesign Checklist [32] \\
\hline MET [32] & PILOT [47] \\
\hline Indicator & Lists \\
\hline MIPS [33] & Volvo's black, grey, and white material lists [48-50] \\
\hline \multicolumn{2}{|l|}{ Energetic content [34] } \\
\hline Environmental indicators [35] & - $\quad$ Objectives and Ideas generation \\
\hline Eco-indicator 99 [36] & $\begin{array}{l}\text { TRIZ [51] } \\
\text { ecoASIT [52] }\end{array}$ \\
\hline Classical methods & EcoMal' in [53] \\
\hline Green-QFD [37], QFDE [38], ECQFD [39] & Lifecycle Design Strategy wheel [32] \\
\hline Eco-VA [40] & PIT diagram [54] \\
\hline EEA [41] & Eco-ideation and assessing the implementation difficulty and emissions benefits of innovations $[55,56]$ \\
\hline \multicolumn{2}{|l|}{ Others } \\
\hline \multicolumn{2}{|l|}{ Environmental material selection charts [42] } \\
\hline \multicolumn{2}{|l|}{ Eco-functional matrix [43] } \\
\hline Lifecycle brick [44] & \\
\hline
\end{tabular}

Some authors $[23,24]$ compared evaluation tools with diagnosis tools. While the firsts are generally analysis tools i.e. they allow a detailed study of the entire product system, the seconds are approximate and their evaluation modes differ: quantitative, semi-quantitative, and qualitative. Nevertheless, these evaluation modes are complementary. It is therefore relevant to check the reliability of the results of evaluation tools.

The list of eco-design tools and methods in Table 1 is not exhaustive. This classification is inspired from the previous classifications. We consider two classes: the tools for diagnosis which can be analysis or evaluation tools, and the tools for improvement which can be recommendation or ideation and objectives generation. The next part of this paper deals with the models of design process, particularly the RID model which seems relevant for our goal to integrate the dimension " $E$ " in the Innovation structure.

\section{TOWARD THE CONCEPT OF RID}

Eco-design methods and tools must lie within the design and innovation processes. The complexity of these processes asks to use models in order to have a better illustration. In her $\mathrm{PhD}$ thesis, Lahonde [57] carried out a synthesis of five models of design process: Axiomatic Design [58], Design for Six Sigma [59], New Product Design [60], Systematic Design [61], and TRIZ [62]. Although each model has its own characteristics and objectives, Lahonde highlighted similarities: per phase breakdown, or iterations. Her comparison table identifies five phases: Preparation, Identification, Design 1, Design 2, Manufacturing. The international standard ISO 14062 [63] about the integration of environmental aspects into the product design and development introduces one generic model in six stages: Planning, Conceptual design, Detailed design, Testing/prototype, Production/Market launch, Product review. These models are not sufficient to establish the specifications for integrating an eco-design method for a designer of complex systems; that leads us to explore the innovative nature of design.

From the study of innovative companies, Hatchuel et al. [64] searched for understanding how the organization of a company must change in order to generate innovations. They recommend the use of the concept of RID (Research, Innovation structure, and Development) instead of the usual $\mathrm{R} \& \mathrm{D}$ concept, where I is "a structured process, with its specific management principles which are different from respectively $R$ and $D$ activities". They defined the three functions from a managerial point of view: "if research is a controlled process of knowledge production that is not in charge of values definition, and if development requires competencies and value definition, we can define the Innovation structure as being in charge of a twofold design work:

- A Value definition process

- New competencies identification process".

Figure 2 shows all interactions between the three functions. 


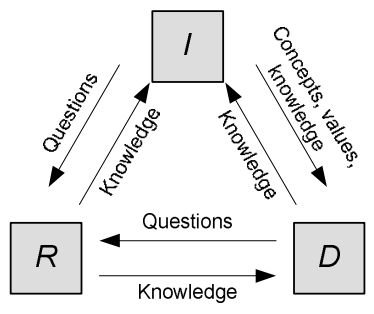

FIGURE 2 - RELATIONSHIPS BETWEEN R, I AND D [64]

According to the authors, the companies in the automotive industry are good examples of the application of the concept of RID; Buet et al. [11] remind that innovative design projects are distinguished from the vehicle development projects. Therefore, the specifications of an eco-design method for the development are different from those for the Innovation structure. This method should meet the twofold activity defined by Hatchuel et al.: the dimension "E" must be perceived as a new value for the designers and generate new concepts and knowledge. The ecodesign method for the Innovation structure must generate:

- ideas and products ready for development, and emerging product concepts at various formalization stages, thanks to one "toolbox environment" discussed in the first part of this paper,

- new emerging competencies allowing the valorization of the dimension " $\mathrm{E}$ ".

Moreover, the method must be adapted to the different technology readiness levels of the innovation which are measurable thanks to the scale defined by the NASA [65].

In the following part, we make a synthesis of the main actions of different car makers and link the practices of three of them with the concept of RID.

\section{INTEGRATION STRATEGY FROM THE AUTOMOTIVE INDUSTRY}

Car makers and part suppliers must increasingly take into account the dimension "E" within the design process. Nevertheless, their publications are still rare. The nonexhaustive list in the Table 2 gives some actions of companies in the worldwide automotive industry. We make a distinction between LCA studies and eco-design methods: the bibliographical references for LCA studies concern case studies in the automotive sector or improvement of the methodology itself, while the aim of those of the eco-design method list is to improve the product by using a system of tools which may include the LCA and the relations of these tools within the design process.

Conducting LCA may lead car manufacturers to publish Environmental Product Declarations (EPD). For example, since 2007 Volkswagen has published on its website ${ }^{1}$ eleven Environmental Commendations for vehicles (Passat, Golf, Polo $\ldots$, one engine (TSI Engine) and one gearbox (Dual-Clutch

${ }^{1}$ http://www.volkswagen.com/vwcms/master_public/virtualmaster/en2/unt ernehmen/mobility and sustainability0/service/download/Download en.html (accessed 12/07/2011) gearbox). Volvo ${ }^{2}$ has made a simulator of EPD available to the website visitors.

Chanaron made a benchmark of best practices in LCA from European car makers: DaimlerChrysler, Ford Motor and Volkswagen [91]. One of his conclusions is that car manufacturers use the LCA methodology for "assessing innovative technologies and vehicles of the future." Nunes and Bennett analyzed the "green" initiatives of three manufacturers namely Toyota, General Motors and Volkswagen, particularly concerning the eco-design [92]. They observed that they mainly focus on the improvement of internal combustion engines, e.g. fuel reduction, alternative driving chain, or alternative fuels. However, eco-design approaches and methods do not appear.

Furthermore, some common projects bring together several car makers such as the LIRECAR project about the LCA of lightweight and end-of life scenarios [93], or the project on an "Environmentally Friendly Vehicle concept" [94] where they recommend to avoid a single score for the environmental assessment of a vehicle.

In order to build a strategy for integrating the dimension "E" in the innovative structure, we propose a focus on the strategies adopted by three car makers: Volvo, Ford and Volkswagen. The strategies are connected with the concept of RID.

Volvo The Swedish car maker began researches on LCA in 1989 [88]. This action aimed to product knowledge through a controlled process, which is the definition of the function $\mathrm{R}$. Then, these researches resulted in the EPS method (Environmental Priority Strategies in design) in co-operation with the Federation of Swedish Industries. This method enables the agglomeration of "all the data coming from the inventory phase of a LCA to one single value, expressed in Environmental Load Unit (or ELU)" [89]. The EPS method was computerized for being used by LCA non-experts such as designers. In 1996 [95], the SPINE database (Sustainable Product Information Network for the Environment) is developed in order to "facilitate the exchange of LCA data and improve the operational implementation of LCA methods". The EPS method, its computerization, and the SPINE database fulfill the requirements of the function $D$ i.e. the activation of environmental knowledge so as to specify the product for evaluating its environmental profile. In 1997, the company began to work with the Environmental Effect Analysis (EEA) which comes from an adaptation of the "Failure Mode Effect Analysis" to the environment. It clearly transforms the environment into a new value and brings to designers new concepts for improving their products, which are the requirements of the function I. Tingström and Karlsson [90] analyzed the relations between LCA and EEA by focusing on the integration in the design process. From the interviews they made with Volvo's teams, they concluded that "the problem was to make the environmental information effective, by making

${ }^{2}$ http://www.volvotrucks.com/dealers-vtc/en-gb/VTBCEastAnglia/aboutus/environment/environmental product declaration/Pages/Intr oduction.aspx (accessed 12/07/2011) 
it readily available early enough to make it useful to influence the environmentally relevant design decisions"; Volvo's teams therefore prefer using EEA early in the design process. Moreover, Tingström [96] remarked that "a radical innovation should use EEA as a supporting tool, and incremental innovation should use LCA". Volvo's strategy is shown in Figure 3.

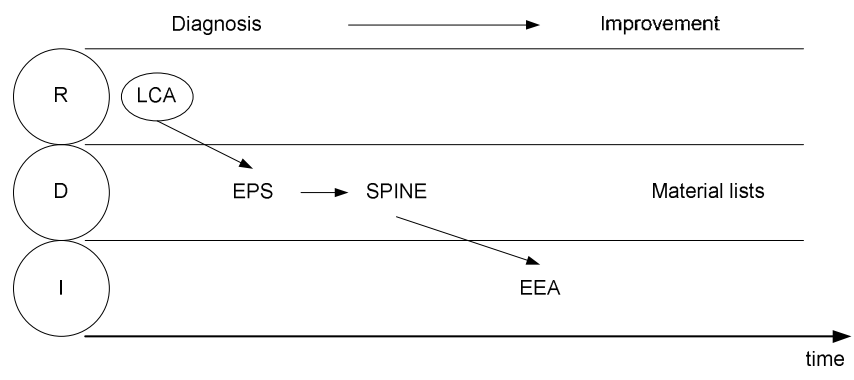

FIGURE 3 - VOLVO'S STRATEGY

TABLE 2 - ENVIRONMENTAL ACTIONS OF CAR MANUFACTURERS AND PART SUPPLIERS

\begin{tabular}{|c|c|c|}
\hline $\begin{array}{l}\text { Car maker / Part } \\
\text { supplier }\end{array}$ & Country & Studies in LCA \\
\hline Daimler AG & Germany & $\begin{array}{l}\text { Supplying databases on manufacturing processes (gear wheel of } \\
\text { the front-shift transmission for Daimler AG; valve injector for } \\
\text { Bosh GmbH) [66] } \\
\text { Application of Life Cycle Assessment for the Environmental } \\
\text { Certificate of the Mercedes-Benz S-Class [67] }\end{array}$ \\
\hline Faurecia & France & \\
\hline $\begin{array}{l}\text { Ford-Werke GmbH } \\
\text { / Ford Motor }\end{array}$ & $\begin{array}{l}\text { Germany / } \\
\text { USA }\end{array}$ & $\begin{array}{l}\text { Streamlined LCA of the recovery of battery-housing [70] } \\
\text { Weighting in Life Cycle Assessments in a Global Context [71] }\end{array}$ \\
\hline General Motors & USA & Comparison of two fuel tank system designs [75] \\
\hline $\begin{array}{l}\text { PSA } \quad \text { Peugeot } \\
\text { Citroën }\end{array}$ & France & $\begin{array}{l}\text { Comparative LCA of several end-of life scenarios for a } \\
\text { polypropylene bumper skin [76] } \\
\text { Preliminary study for a comparative LCA of a classical vehicle and } \\
\text { a hybrid electric vehicle [77] }\end{array}$ \\
\hline Siemens AG & Germany & \\
\hline Toyota & Japan & $\begin{array}{l}\text { Eco-VAS system including a LCA database and an evaluation tool } \\
\text { for designers during the design process [81] }\end{array}$ \\
\hline Volkswagen AG & Germany & $\begin{array}{l}\text { On the calculation of fuel savings through lightweight design in } \\
\text { automotive life cycle assessments [82] } \\
\text { An integrated approach for environmental assessments using fuzzy } \\
\text { system [83] } \\
\text { Comparative Life Cycle Assessment of Remanufacturing and New } \\
\text { Manufacturing of a Manual Transmission [84] } \\
\text { Comparative LCA of two methods for recycling end-of life } \\
\text { vehicles [85] } \\
\text { Life Cycle Inventory for the Golf A4 [86] } \\
\text { A procedure for streamlined inventory modeling within life cycle } \\
\text { assessment of vehicles [87] }\end{array}$ \\
\hline
\end{tabular}

AB Volvo

Sweden
Eco-design methods

Learning Driving Tool for the design for the valorization of the dimension "E" $[3,68]$

Evaluation method of environmental impacts for the design team [69]

Product Sustainability Index explanations, Demonstration of the validity of a spreadsheet tool for non-experts in LCA [72]

Life Cycle Costing as part of design for environment [73]

Electrical and electronic components in the automotive sector: Economic and environmental assessment [74]

Enhancement of the application efficiency of LCA [97]

Methodology for improving the recovery rate of end-of life vehicles [78]

Evaluation tool of the recovery potential earlier in the design process [79]

Quantitative streamlined LCA: Parameterised inventories and interactions with design parameters [80]

Incorporating sustainability into supply management in the automotive industry [67]

Fitting LCA for the design process [88]

EPS as a Life Cycle oriented System Assessment Tool to Facilitate Industrial Learning about Relations to the Environment [89]

Material lists [48-50]

Using the Environmental Effect Analysis method [90] 
Ford Ford developed in 2006 the Product Sustainability Index (PSI) by conducting researches in the LCA and Life Cycle Costing (LCC) fields. The oldest research in LCA that we found was made in 1999 and aimed to compare end-of life scenarios for a battery housing; the authors conclude that "from a strategic point of view, the simplified LCA is suitable for answering the questions" [70]. In 2002, Schmidt and Sullivan [71] had a part in the LCA methodology by recommending to not using weighting in Life Cycle Impact Assessment. In 2003, Schmidt [73] conducted a research on LCC but concluded that LCC cannot be used by non-experts in life cycle. The thesis of Rebitzer [97] aimed "to simplify the methods of LCA application and to use LCA as a basis for life cycle costing." That leaded in 2006 to the first publication of the PSI applied to Ford's car [72]; three PSI reports are available on the website of the company ${ }^{3}$ for S-Max and Galaxy, Kuga, and Mondeo. The PSI tool "allows non-experts to manage key environmental, social and economic aspects in the product development, also on a vehicle level." Finally, in 2007, LCA and LCC were applied to "define optimum design and end-of-life scenarios" for electrical and electronic components. Ford's strategy is represented in Figure 4. The need to pass from diagnosis to improvement is obvious through the opening of the LCC research field and placing a tool at non LCA experts' disposal.

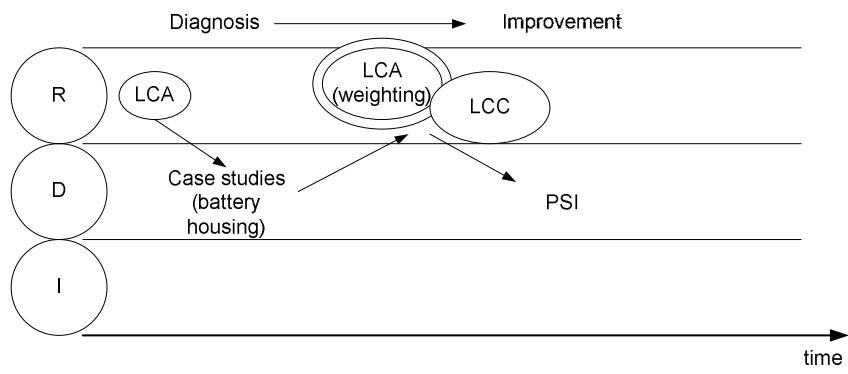

\section{FIGURE 4 - FORD'S STRATEGY}

Volkswagen Volkswagen has begun making Life Cycle Inventory (LCI) since 1992, which leaded to some Environmental Commendations. The company had a part in the LCA methodology in 2008 by developing the slimLCI method to automate LCI [87], and in 2010 by improving the use stage modeling with the Fuel Reduction Value parameter [82]. Moreover, Volkswagen opened a research field on end-of life and compared in 2006 two recycling methods [85]. Finally, Warsen et al. [84] assessed in 2011 the benefits of an innovative end-of life strategy namely the remanufacturing thanks to the LCA methodology; this highlights the complementary aspects of the tools. Volkswagen's strategy is shown in Figure 5. By using the LCA results, Volkswagen tried to strive toward the improvement of the end-of life step with the process SiCon [85] and the remanufacturing strategy [84].

${ }^{3}$ http://www.ford.co.uk/AboutFord/Sustainability/ProductSustainabilityIn dex (accessed 12/13/2011)

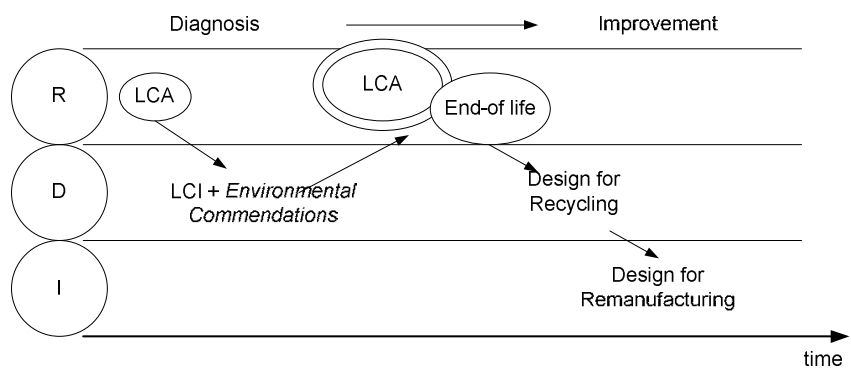

FIGURE 5 - VOLKSWAGEN'S STRATEGY

Looking at the three examples above, as the environment was seen as a constraint, they conducted researches (function $\mathrm{R}$ ) in the LCA field and developed some tools e.g. EPS, PSI, or slimLCI, which leaded the designers to comprehend the dimension "E" as a criterion (function D). Lastly, thanks to tools for the Innovation structure e.g. EEA, the dimension "E" became a value (function I). Therefore, the specifications for our integration method of eco-design in the Innovation structure may be based on these observations.

\section{SPECIFICATIONS FOR INTEGRATING ECO- DESIGN}

The valorization of a dimension has already been studied in the ergonomics field. Millet et al. [10] proposed one model of integration of ergonomics in the design process. This model is based on a downstream approach. Ergonomics must "pass from the newly knowledge coming from the research process to credibility." It is therefore an "intervention based on the downstream parts of design process."

Here we make an analogy between the downstream integration approach of ergonomics and the integration approach of the dimension " $\mathrm{E}$ " in the Innovation structure and try to make a model (Figure 6), based on the concept of RID and the previous examples. The level of maturity of a technology increases during its design process, and generally, the phase Development follows the phase Innovation, which follows the phase Research. Therefore, one of the specifications for our downstream integration approach should first integrate methodological elements in the Development phase to go back to the Innovation structure. These methodological elements are built by the Research function. 


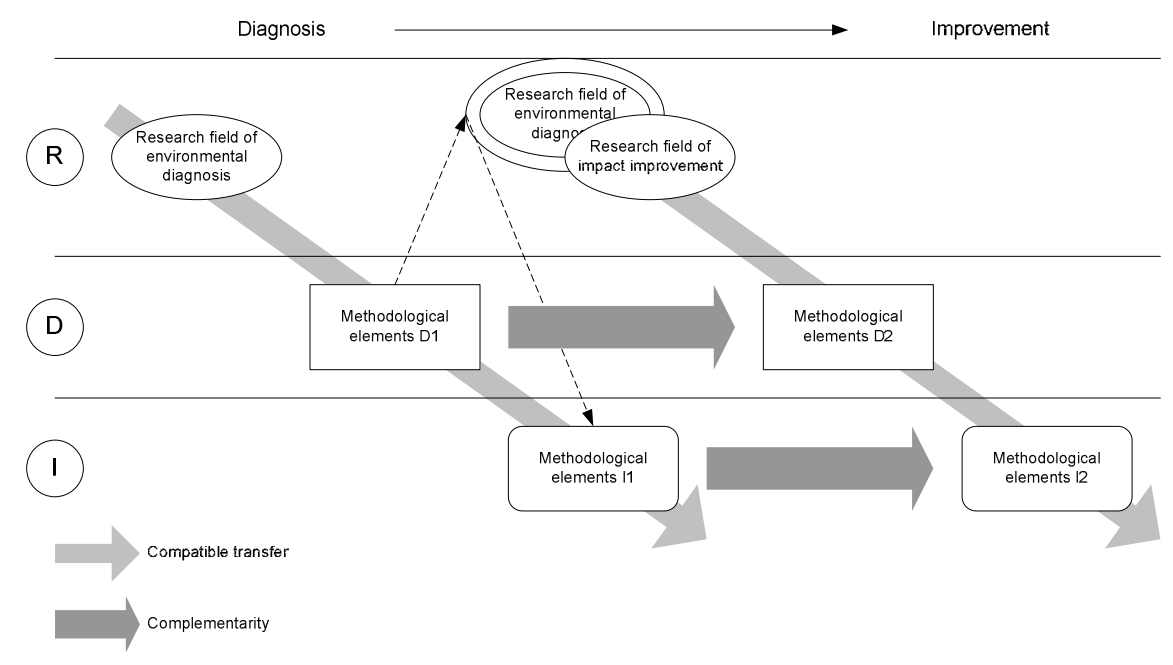

FIGURE 6 - MODEL OF A STRATEGY FOR INTEGRATING THE DIMENSION "E”

By synthetizing the three examples, it seems that the main evolution for integrating the dimension "E" passes from the diagnosis research field to the improvement research field. So it seems relevant first to open a research field which may lead to create, adapt or use methodological elements for analyzing and/or evaluating. The diagnosis leads the company to "know what they do". This is the first sub-process of the complete integration process of Millet et al. [9]. After detecting the forces and weaknesses of their product, the three previous examples seem to act in order to improve their product and so "do what they know". The variety of action kinds is wide and seems to be specific to the company's strategy. This is the second subprocess of Millet et al.. Therefore, a second specification would be the building of both types of tools: diagnosis and improvement.

Finally, the chosen strategy for integrating the dimension "E" must support learning and the creation of knowledge. Each research field generates methodological elements for the Development and the Innovation structure. Therefore, we can define a third specification: according to Millet et al. [10], the transfer in the same research of methodological elements from $\mathrm{D}$ to $\mathrm{I}$, e.g. $\mathrm{D}_{1}$ to $\mathrm{I}_{1}$, must be coherent, and the methodological elements from one research field to another, e.g. $D_{1}$ to $D_{2}$ or $I_{1}$ to $\mathrm{I}_{2}$, must be complementary. As the learning process is driven by the organization and the interactions between the management of firm, the environment department and the design team, collaborations between the environment department and the design team would promote the development of the methodological elements.

\section{CONCLUSION AND PERSPECTIVES}

In this paper we first proposed one synthesis of categorization of eco-design tools; we chose to classify the tools according to their function: diagnosis with analysis and evaluation tools, and improvement with recommendation tools and objective and idea generations. Second, we introduced the concept of RID which highlights the specificities of the Innovation structure. This led us third to look for the practices of car makers and part suppliers and their strategies for integrating the dimension "E". We made a focus on three car manufacturers and connected their strategies with the concept of RID. Then in the fourth part, we proposed one model based on the analysis of the three examples for an integration strategy of the dimension "E" supported by a learning process.

We did not propose any methodological elements and we highlighted that they are specific to the company. They may be extracted from the scientific literature, adapted, or created. Nevertheless, they should be developed by collaboration between the environment department and the design team. Moreover, the trajectory of the use of the tools has not been studied, only mentioned in the Volvo's example. In perspectives, these observations ask for some researches and a collaborative work for building the methodological elements, so as to be tested in a company.

\section{REFERENCES}

[1] United Nations World Commission on Environment and Development, (1987). "Our Common Future". Oxford University Press, London.

[2] Karlsson R., Luttropp C., (2006). "EcoDesign: what's happening? An overview of the subject area of EcoDesign and of the papers in this special issue". J. Clean. Prod., 14 (15-16), pp. 1291-1298.

[3] Jacqueson L., Millet D., Aoussat A., (2001). "Integration of the Environment in the Product Design Process: Proposal for a Learning Driving Tool". Eigth International Symposium on the Management of Industrial and Corporate Knowledge.

[4] Baumann H., Boons F., Bragd, A., (2002). "Mapping the green product development field: engineering, policy and business perspectives". J. Clean. Prod., 10 (5), pp. 409-425. 
[5] Fargnoli M., Kimura F., (2007). "The Optimization of the Design Process for an Effective Use in Eco-Design". 14th CIRP International Conference on Life Cycle Engineering, pp. 59-64. [6] Bras B., (1997). "Incorporating Environmental Issues in Product Design and Realization". Industry and Environment, 20 (1-2), pp. 7-13.

[7] Millet D., Bistagnino L., Lanzavecchia C., Camous R. (2003). "The firm faced to sustainable development: change of paradigm and learning process". Nature Sciences Sociétés, 11 (2), pp. 146-157.

[8] Millet D., Coppens C., Jacqueson L., Le Borgne R., Tonnelier P., (2003). "Intégration de l'environnement en conception - L'entreprise et le développement durable». Hermes Science, Paris.

[9] Millet D., Bistagnino L., Camous R., Aoussat A., (2004). "Integration of new dimensions in design process. Application to the environmental dimension". In: Tichkiewitch S., Brissaud D. (Eds.) "Methods and Tools for Co-operative and Integrated Design", Kluwer Academic Publishers.

[10] Millet D., Minel S., Vallette T., (2006) «Intégration de l'ergonomie dans la conception de produits mécaniques ». In: Roucoules L. et al. (Eds.) «Ingénierie de la conception et cycle de vie des produits (Traité IC2, série Productique)», Hermes Science Publishing.

[11] Buet G., Gidel T., Millet D., (2010). "Integrating innovations into vehicle projects - towards a robust "touch down" process". Proceedings, Global Product Development: 20th CIRP Design Conference, pp. 117-126.

[12] Le Pochat S., Bertoluci G., Froelich D., (2007). "Integrating ecodesign by conducting changes in SMEs". $J$. Clean. Prod., 15 (7), pp. 671-680.

[13] Janin M., (2000). «Démarche d'éco-conception en entreprise - Un enjeu : Construire la cohérence entre outils et processus ». Ecole Nationale Supérieure des Arts et Métiers, $\mathrm{PhD}$ thesis.

[14] Tischner U., Nickel R., (2003). "Eco-design in the printing industry - Life cycle thinking: Implementation of Eco-design concepts and tools into the routine procedures of companies". J. Sustainable Prod. Des., 3 (1-2), pp. 19-27.

[15] Van Berkel R., Willems E., Lafleur M., (1997) "Development of an industrial ecology toolbox for the introduction of industrial ecology in enterprises-I". J. Clean. Prod., 5 (1-2), pp. 11-25.

[16] Dewulf W., (2003). "A proactive approach to ecodesign: framework and tools". Katholieke Universiteit Leuven, $\mathrm{PhD}$ thesis.

[17] AFNOR, (2010). "Mechanical products - Eco-design methodology". Association française de normalisation.

[18] Bellini B., Janin M., (2011). «Ecoconception : état de l'art des outils disponibles ». Techniques de l'Ingénieur, G $6010 \mathrm{v} 2$. [19] Bovea M.D., Pérez-Belis V., (2011). "A taxonomy of ecodesign tools for integrating environmental requirements into the product design process". J. Clean. Prod., 20 (1), pp. 61-71. [20] Byggeth S., Hochschorner E., (2006). "Handling trade-offs in Ecodesign tools for sustainable product development and procurement". J. Clean. Prod., 14 (15-16), pp. 1420-1430.
[21] Knight P., Jenkins J.O., (2009). "Adopting and applying eco-design techniques: a practitioners perspective". J. Clean. Prod., 17 (5), pp. 549-558.

[22] Ilgin M.A., Gupta S.M., (2010). "Environmentally conscious manufacturing and product recovery (ECMPRO): A review of the state of the art". J. Environ. Manage., 91 (3), pp. 563-591.

[23] Hochschorner E., Finnveden G., (2003). "Evaluation of Two Simplified Life Cycle Assessment Methods". Int. J. Life Cycle Assess., 8 (3), pp. $119-128$.

[24] Hur T., Lee J., Riu J., Kwon E., (2005) "LCA and matrix methods in identifying the environmental aspects of a product system". J. Environ. Manage., 75 (3), pp. 229-237.

[25] ISO 14040, (2006). "Environmental management - Life cycle assessment - Principles and framework". International Standard Organization.

[26] ISO 14044, (2006). "Environmental management - Life cycle assessment - Requirements and guidelines". International Standard Organization.

[27] Finnveden G., Hauschild M.Z., Ekvall T., Guinée J., Heijungs R., Hellweg S., Koehler A., Pennington D., Suh S., (2009). "Recent developments in Life Cycle Assessment". $J$. Environ. Manage., 91 (1), pp. 1-21.

[28] Graedel T.E., (1998). "Streamlined life-cycle assessment". Prentice Hall.

[29] Wenzel H. (1998). "Application dependency of LCA methodology: Key variables and their mode of influencing the method". Int. J. Life Cycle Assess., 3 (5), pp. 281-288.

[30] Wenzel H., Hauschild M., Alting L., (1997). "Environmental Assessment of Products, Vol. 1: Methodology, Tools and Case Studies in Product Development". Chapman \& Hall, London.

[31] Graedel T.E., (1996) "Weighted matrices as product life cycle assessment tools". Int. J. Life Cycle Assess., 1 (2), pp. 8589.

[32] Brezet H., van Hemel C., (1997) "Ecodesign, A promising approach to sustainable production and consumption". United Nations Environment Programme, Paris.

[33] Ritthoff M., Rohn H., Liedtke C., (2002) "Calculating MIPS : Resource Productivity of Products and Services. Wuppertal Institute for Climate, Environment and Energy. http://www.wupperinst.org/uploads/tx_wibeitrag/ws27e.pdf (accessed 11/25/2011).

[34] Lenau T., Bey N., (2001). "Design of environmentally friendly products using indicators", Proceedings of the Institution of Mechanical Engineers, Part B: Journal of Engineering Manufacture, 215 (5), pp. 637-645.

[35] Jasch C., (2000) "Environmental performance evaluation and indicators". J. Clean. Prod., 8 (1), pp. 79-88.

[36] Goedkoop M., Spriensma R., (2000). "The Eco-indicator 99 - A damage oriented method for Life Cycle Impact Assessment - Methodology Report". PRé Consultants B.V., Amersfoort, The Netherlands. http://simapro.rmit.edu.au/LIT/LCA/EI99_METHODOLOGY V2.PDF (accessed 12/3/2011). 
[37] Zhang Y., Wang H.-P., Zhang C., (1999). "Green QFD-II: A life cycle approach for environmentally conscious manufacturing by integrating LCA and LCC into QFD matrices". Int. J. Prod. Res., 37 (5), pp.1075 - 1091.

[38] Masui K., Sakao T., Kobayashi M., Inaba A., (2003) "Applying Quality Function Deployment to environmentally conscious design". International Journal of Quality \& Reliability Management, 20 (1), pp. 90-106.

[39] Vinodh S., Rathod G., (2010). "Integration of ECQFD and LCA for sustainable product design". J. Clean. Prod., 18 (8), pp. 833-842.

[40] Sakao T., Oberender C., Krone N., Shimomura Y., Birkhofer H., Reichl H., (2006). "Evaluating Customer Requirements in Eco-VA". 13th CIRP International Conference on Life Cycle Engineering, pp. 519-524.

[41] Lindhal M. (2000). "Environmental Effect Analysis (EEA) - An approach to Design for Environment". KTH Royal Institute of Technology, Licentiate thesis.

[42] Holloway L., (1998). "Materials selection for optimal environmental impact in mechanical design". Mater. Design, 19 (4), pp. 133-143.

[43] Lagerstedt J., (2003) "Functional and environmental factors in early phases of product development - Eco functional matrix". KTH Royal Institute of Technology, $\mathrm{PhD}$ thesis.

[44] Gehin A., Zwolinski P., Brissaud D., (2009). "Integrated design of product lifecycles - The fridge case study". CIRP Journal of Manufacturing Science and Technology, 1 (4), pp. 214-220.

[45] Holt R., Barnes C., (2010) "Towards an integrated approach to "Design for X": an agenda for decision-based DFX research". Res. Eng. Des., 21 (2), pp.123-136.

[46] Luttrop C., Lagerstedt J., (2006). "EcoDesign and The Ten Golden Rules: generic advice for merging environmental aspects into product development". J. Clean. Prod., 14 (15-16), pp. 1396-1408.

[47] Wimmer W., Züst R., (2002) "ECODESIGN Pilot Product-Investigation-, Learning- and Optimization- Tool for Sustainable Product Development". Kluwer Academic Publishers, Dordrecht, The Netherlands.

[48] Volvo, (2010). "Chemical substances which must not be present in processes or products within the Volvo Group Volvo's black list", http://www.volvologistics.com/SiteCollectionDocuments/1000002\%20Black\%20list.pdf (accessed 11/25/2011)

[49] Volvo, (2010). "Chemical substances which should not be present in processes or products within the Volvo Group Volvo's grey list". http://www.volvologistics.com/SiteCollectionDocuments/1000003\%20Grey\%20list.pdf (accessed 11/25/2011).

[50] Volvo, (2009). "Substitutes for hazardous chemical substances - Volvo's white list". http://www.volvologistics.com/SiteCollectionDocuments/1000004\%20White\%20list.pdf (accessed 11/25/2011).

[51] Chen L.J., Liu C.-C., (2001). "An eco-innovative design approach incorporating the TRIZ method without contradiction analysis”. J. Sustainable Prod. Des., 1, pp. 263-272.
[52] Tyl B., Legardeur J., Millet D., Vallet F., (2010). "Stimulate Creative Ideas Generation for Eco-Innovation: an Experimentation to Compare Eco-Design and Creativity Tools". Research in Interactive Design, 3, paper GEDI_P125.

[53] Samet W., Ledoux Y., Nadeau J.-P., (2010). "Ecoinnovation Tool for Mal'in Software, Application on a Waffle Iron". Research in Interactive Design, 3, paper GEDI_P121.

[54] Jones E., Stanton N. A., Harrison D., (2001). “Applying structured methods to Eco-innovation. An evaluation of the Product Ideas Tree diagram". Design Studies, 22 (6), pp. 519 542.

[55] Bocken N.M.P., Allwood J.M., Willey A.R., King J.M.H., (2011). "Development of an eco-ideation tool to identify stepwise greenhouse gas emissions reduction options for consumer goods". J. Clean. Prod., 19 (12), pp. 1279-1287.

[56] Bocken N.M.P., Allwood J.M., Willey A.R, King J.M.H., (2011). "Development of a tool for rapidly assessing the implementation difficulty and emissions benefits of innovations". Technovation.

[57] Lahonde N., (2010). «Optimisation du processus de conception : Proposition d'un modèle de sélection des méthodes pour l'aide à la décision». Ecole Nationale Supérieure des Arts et Métiers, $\mathrm{PhD}$ thesis.

[58] Suh N.P., (1990). «The Principles of Design». Oxford University Press, Oxford, UK.

[59] Mader D.M., (2002). "Design For Six Sigma”. Quality Progress, pp.82-86.

[60] Aoussat A., (1990). «La pertinence en Innovation: Nécessité d'une Approche Plurielle». Ecole Nationale Supérieure des Arts et Métiers, $\mathrm{PhD}$ thesis.

[61] Pahl G., Beitz W., Feldhusen J., Grote K.H., (2007). "Engineering Design: A Systematic Approach". Springer.

[62] Cavallucci D., (1999). « L' approche altshullerienne de la créativité ». Techniques de l'Ingénieur, A 5211.

[63] ISO 14062, (2002). "Environmental management Integrating environmental aspects into product design and development". International Standard Organization.

[64] Hatchuel A., Le Masson P., Weil B., (2001). "From R\&D to RID : Design Strategies and the Management of Innovation Fields". 8th International Product Development Management Conference, pp.415-430.

[65] Mankins J.C., (2009). "Technology readiness assessments: A retrospective". Acta Astronaut., 65 (9-10), pp. 1216-1223.

[66] Schlosser R., Klocke F., Döbbeler B., Riemer B., Hameyer K., Herold T., Zimmermann W., Nuding O., Schindler B.A., Niemczyk M., (2011). "Assessment of Energy and Resource Consumption of Processes and Process Chains within the Automotive Sector". 18th CIRP International Conference on Life Cycle Engineering, pp. 45-50.

[67] Finkbeiner M., Hoffmann R., Ruhland K., Liebhart D., Stark B., (2006). "Application of Life Cycle Assessment for the Environmental Certificate of the Mercedes-Benz S-Class". Int. J. Life Cycle Assess., 11 (4), pp. 240-246.

[68] Jacqueson L., Millet D., Aoussat A., (2003). "Integration of the environment in product design by a learning process: 
proposal for a piloting tool". Int. J. Environ. Pollut., 19 (4), pp. 317-335.

[69] Andriankaja H., Bertoluci G., Vasilescu C., (2009). "Developing a Robust System of Environmental Tools (RSET) to Improve Ecodesign Practice in the Automotive Sector". ASME 2009 International Design Engineering Technical Conferences, paper DETC2009-86591, pp. 245-256.

[70] Schmidt W.-P., Beyer H.-M., (1999). "Environmental considerations on battery-housing recovery". Int. J. Life Cycle Assess., 4 (2), pp. 107-112.

[71] Schmidt W.-P., Sullivan J., (2002). "Weighting in Life Cycle Assessments in a Global Context". Int. J. Life Cycle Assess., 7 (1), pp. 5-10.

[72] Schmidt W.-P., Butt F., (2006). "Life Cycle Tools within Ford of Europe's Product Sustainability Index - Case Study Ford S-MAX \& Ford Galaxy”. Int. J. Life Cycle Assess., 11 (5), pp. 315-322.

[73] Schmidt W.-P., (2003). "Life Cycle costing as part of design for environment - Environmental business cases". Int. J. Life Cycle Assess., 8 (3), pp. 167-174.

[74] Alonso J.C., Dose J., Fleischer G., Geraghty K., Greif A., Rodrigo J., Schmidt W.-P., (2007). "Electrical and electronic components in the automotive sector: Economic and environmental assessment". Int. J. Life Cycle Assess., 12 (5), pp. 328-335.

[75] Keoleian G.A., Spatari S., Beal R.T., Stephens R.D., Williams R.L., (1998). "Application of life cycle inventory analysis to fuel tank system design". Int. J. Life Cycle Assess., 3 (1), pp. 18-28.

[76] Le Borgne R., Feillard P., (2001). "End-of-life of a polypropylene bumper skin - Some key elements for a pragmatic environmental management". Int. J. Life Cycle Assess., 6 (3), pp. 167-176.

[77] Garcia J., Tonnelier P., (2010). "Preliminary study for a Life Cycle Assessment of Hybrid Electric Vehicle". Research in Interactive Design, 3, paper GEDI_P123.

[78] Coppens C., Le Coq M., Millet D., Michaud P., (2002). "Evaluating and improving the recovery aptitude of an automobile function: The PSA approach". Int. J. Veh. Des., 29 (4), pp. 307-316.

[79] Tonnelier P., Millet D., Richir S., Lecoq M., (2005). "Is it possible to evaluate the recovery potential earlier in the design process? Proposal of a qualitative evaluation tool". J. Eng. Des., 16 (3), pp. 297-309.

[80] Mueller K.G., Lampérth M.U., Kimura F., (2004). "Parameterised inventories for life cycle assessment Systematically relating design parameters to the life cycle inventory". Int. J. Life Cycle Assess., 9 (4), pp. 227-235.

[81] Nakano K., Hirao M., (2011). "Collaborative activity with business partners for improvement of product environmental performance using LCA”. J. Clean. Prod., 19 (11), pp. 11891197.

[82] Koffler C., Rohde-Brandenburger K., (2010). "On the calculation of fuel savings through lightweight design in automotive life cycle assessments". Int. J. Life Cycle Assess., 15 (1), pp. 128-135.
[83] Thiel C., Seppelt R., Müller-Pietralla W., Richter O., (1999). "An integrated approach for environmental assessments - Linking and integrating LCI, environmental fate models and ecological impact assessment using fuzzy expert systems". Int. J. Life Cycle Assess., 4 (3), pp. 151-160.

[84] Warsen J., Laumer M., Momberg W., (2011). "Comparative Life Cycle Assessment of Remanufacturing and New Manufacturing of a Manual Transmission". 18th CIRP International Conference on Life Cycle Engineering, pp. 67-72. [85] Krinke S., Boßdorf-Zimmer B., Goldmann D., (2006). "The Volkswagen-SiCon Process: Eco-efficient solution for future end-of life vehicle treatment". 13th CIRP International Conference on Life Cycle Engineering, pp. 359-364.

[86] Schweimer G.W., Levin M., (2000). "Life Cycle Inventory for the Golf A4". Volkswagen AG.

[87] Koffler C, Krinke S., Schebek L., Buchgeister J., (2008). "Volkswagen slimLCI: a procedure for streamlined inventory modelling within life cycle assessment of vehicles". Int. J. Veh. Des., 46 (2), pp. 172-188.

[88] Louis S., Wendel A., (1998). "Life Cycle Assessment and Design - Experience from Volvo Car Corporation". SAE International Congress \& Exposition, Paper Number: 980473.

[89] Karlsson R., Steen B., Wendel A., (1997). "EPS as a life cycle oriented system assessment tool to facilitate industrial learning about relations to the environment". Proceedings of the 15th International System Dynamics.

[90] Tingström J., Karlsson R., (2006). "The relationship between environmental analyses and the dialogue process in product development". J. Clean. Prod., 14 (15-16), pp. 14091419.

[91] Chanaron J.-J., (2007). "Life Cycle Assessment practices: benchmarking selected European automobile manufacturers". International Journal of Product Lifecycle Management, 2 (3), pp. 290-311.

[92] Nunes B., Bennett D., (2010). “Green operations initiatives in the automotive industry: An environmental reports analysis and benchmarking study". Benchmarking: An International Journal, 17 (3), pp. 396-420.

[93] Schmidt W.-P., Dahlqvist E., Finkbeiner M., Krinke S., Lazzari S., Oschmann D., Pichon S., Thiel C., (2004). "Life cycle assessment of lightweight and end-of-life scenarios for generic compact class passenger vehicles”. Int. J. Life Cycle Assess., 9 (6), pp. 405-416.

[94] Schmidt W.-P., Morel S., Ruhland K., Krinke S., Kunne B., (2010). "Feasibility of a globally harmonised Environmentally Friendly Vehicle concept". Int. J. Veh. Des., 53 (1-2), pp. 4-15. [95] Curran M.A., Notten P., (2006). "Summary of Global Life Cycle Inventory Data Resources". Prepared for: Task Force 1: Database Registry, SETAC/UNEP Life Cycle Initiative.

[96] Tingström J., (2005). "The Challenge of Environmental Improvement in Different Types of Innovation Projects". Advances in Integrated Design and Manufacturing in Mechanical Engineering, pp. 33-44.

[97] Rebitzer G., (2005). "Enhancing the application of life cycle assessment for industrial uses". Ecole Polytechnique Fédérale de Lausanne, $\mathrm{PhD}$ thesis. 